\title{
Expediciones, fotografía y coleccionismo entre dos siglos. Itinerarios visuales de un cultural broker en Argentina y Paraguay
}

por

\author{
Mariana Giordano ${ }^{1}$ \\ CONICET/UNNE
}

En este artículo se analiza el entramado de visualidad, artefactualidad y coleccionismo en la trayectoria de Louis de Boccard, un "cultural bróker» o «intermediario cultural», que vivió y recorrió Argentina y Paraguay entre fines del siglo XIX y el siglo XX. Su colección se construye desde una narrativa visual y textual que remite a cuestiones de colonialidad, de identidad, de memoria, de conocimiento, con una densidad significante donde la fotografia y el álbum ocupan roles relevantes. Los álbumes son analizados desde una interacción entre las dimensiones visible y enunciable.

Palabras Claves: Argentina-Paraguay; fotografia; coleccionismo; Louis de Boccard.

Cómo CitAR este artículo / Citation: Giordano, Mariana, «Expediciones, fotografía y coleccionismo entre dos siglos. Itinerarios visuales de un cultural broker en Argentina y Paraguay», Revista de Indias, LXXIX/275 (Madrid, 2019): 235-263. https://doi.org/10.3989/revindias.2019.008.

... la vida de los otros, tal como nos llega en la llamada realidad, no es cine sino fotografía, es decir que no podemos aprehender la acción sino tan solo sus fragmentos eleáticamente recortados... Al final, queda un álbum de fotos, de instantes fijos: jamás el devenir realizándose frente a nosotros, el paso del ayer al hoy, la primera aguja del olvido en el recuerdo. (Julio Cortázar, Rayuela, Buenos Aires, Alfaguara, 2013: 611).

En el año 2007 me encontraba en Asunción (Paraguay), consultando colecciones privadas de fotografías y postales sobre indígenas del Gran Chaco,

\footnotetext{
1 marianalgiordano@gmail.com, ORCID iD: https://orcid.org/0000-0002-2730-3701.
} 
cuando di con un conjunto de seis álbumes con fotografías de fines del siglo XIX y principios del XX de un inmigrante suizo radicado primero en Argentina y luego en Paraguay. Se trataba de la llamada Colección Machuca ${ }^{2}$.

En ese momento, y dado que entonces mi interés estaba centrado en la representación del indígena, uno de esos álbumes llamó especialmente mi atención, el que compilaba imágenes de una Expedición al Chaco Paraguayo y al Mato Grosso. Sin embargo, registré también los otros álbumes. Su autor, Louis de Boccard, «explorador» — tal como se autodenominaba en los álbumes-, me pareció un viajero itinerante como tantos otros que a fines del siglo XIX se movilizaron por estas regiones.

Al poco tiempo identifiqué dos álbumes más atribuidos a De Boccard en el Centro de Artes Visuales Museo del Barro ${ }^{3}$, sito en Asunción, y al analizarlos observé que algunas de las fotografías se repetían en los hallados anteriormente, a la vez que advertí que muchas de las imágenes - atribuidas al viajero suizo, tanto por la institución que las acogía, como por los periodistas que habían escrito sobre ellas - , pertenecían a expediciones en las que dudosamente De Boccard pudo haber participado. En ese momento, no atrajo mi atención el análisis de la colección en su conjunto y me centré en el álbum que contenía imágenes de la expedición al Chaco Paraguayo y al Mato Grosso.

En 2013, al iniciar un proyecto sobre expediciones en el Gran Chaco, retomé aquellos álbumes con dos intenciones: por un lado, buscar los medios para poner en valor esa colección que estaba en mal estado de conservación; y por otro, indagar el rol que la imagen y la mirada tuvo en el contexto histórico particular del Gran Chaco, que se extendía desde la finalización de la ocupación de esos territorios por los Estados Nacionales hasta el inicio de la Guerra del Chaco entre Bolivia y Paraguay.

Así, al comenzar a buscar información sobre este personaje, Louis de Boccard, contacté con su familia en Suiza que me brindó artículos periodísticos y algunos escritos. Simultáneamente, un fotógrafo suizo llamado Nicolás Savary se puso en contacto conmigo y aseveró contar con varios álbumes, cartas y otra documentación de importancia (Colección Théo Savary), que había pertenecido al personaje que nos ocupa ${ }^{4}$. Al año siguiente, 2014, inicia-

2 Colección Machuca, Asunción, Paraguay, colección privada (en adelante Colección Machuca). Así se llamaba esta colección cuando realizamos la investigación y escribimos este artículo.

${ }^{3}$ Centro de Artes Visuales Museo del Barro, generalmente conocido como Museo del Barro, Asunción, Paraguay (en adelante Museo del Barro).

${ }^{4}$ El fotógrafo suizo era Nicolas Savary. Su padre, Théo Savary, había encontrado esta colección en la ciudad de Friburgo, en un día lluvioso, arrojada en la basura. Rescató parte 
mos juntos el rescate de otra parte importante de objetos, álbumes y documentación varia que los descendientes de De Boccard radicados en Areguá (Paraguay) conservaban y que se denomina Colección Monges ${ }^{5}$.

De este modo, me encontré con material visual, objetual y documental sobre el Gran Chaco y sobre diversos espacios de la Argentina que comprenden la ciudad y Provincia de Buenos Aires, la Patagonia y Cuyo, Chile y Paraguay. También advertí que esa inmensidad de objetos habían itinerado por diversos ámbitos del Viejo Mundo y del Cono Sur Americano, y que hoy se hallaban desperdigados, ya que en su «vida social» ${ }^{6}$ asumieron diversas valoraciones según los contextos culturales que los observaron y los sujetos que las poseyeron.

Años atrás consideré que esta colección de objetos no podía o no merecía ser estudiada, pero más adelante, tras llevar a cabo un objetivo primer análisis, cambió mi percepción sobre el nuevo contexto de relaciones objetuales, sociales, científicas y políticas que surgía ante mí. Me encontré ante este corpus que fui construyendo como investigadora, pero también como espectadora: construirlo y delimitarlo fue como dar un encuadre a una escena fílmica, función que se realiza en todo trabajo de investigación. Pero también, atendiendo a los aportes de los estudios culturales, no podía dejar de lado la subjetividad espectatorial que estos artefactos me producían, incorporándome en el entramado de la historia de los mismos en tanto investigadora/consumidora.

La abundancia de producción visual de De Boccard, reconozco, me seducía. Fue la lectura y el diálogo entre los diferentes artefactos y documentos, desde presupuestos de los estudios visuales y culturales, lo que comenzó a transformar a un sujeto desconocido por la historiografía en objeto investigable. De Boccard y sus artefactos se agenciaron de mis investigaciones.

En este artículo me propongo analizar el entramado de visualidad, artefactualidad y coleccionismo que hay en la trayectoria de un personaje con múl-

de la documentación, la que pudo y la que le pareció más valiosa, pero, entre la que se perdió, se encontraban varios diarios. Esta colección se conoce como Colección Théo Savary, Suiza, colección privada (en adelante Colección Théo Savary). Así se llamaba esta colección cuando realizamos la investigación y escribimos este artículo.

5 Colección Monges, Areguá, Paraguay, colección privada (en adelante Colección Monges). Así se llamaba esta colección cuando realizamos la investigación y escribimos este artículo. Nicolas Savary realizó, la digitalización de las tres colecciones, por lo que su aporte en este proceso ha sido de gran relevancia. Agradecemos también la colaboración de Martín Romano García.

${ }^{6}$ Appadurai (1991) plantea la vida social de las cosas, que se complementa con la idea de Kopytoff (1991), quien defiende que los objetos tienen historias vitales (una de cuyas fases puede ser mercantil, pero que no se agota en ella), y por ello las cosas tienen una «biografía cultural», en términos de este último autor. 
tiples roles - viajero, explorador, fotógrafo, agente secreto del Estado Argentino, empresario ganadero, agente inmobiliario, entre otras actividades-, a quien ubicamos en lo que Rudolf Wolf denomina «grupos intersticiales» ${ }^{7}$, un cultural broker, un «intermediario cultural» que ocupa un rol articulador en las sociedades complejas y que además, se (re)inventa permanentemente para ocupar ese papel. Si bien los brokers surgen del mismo grupo, en este caso extiendo el concepto atendiendo a un sujeto que fluye en los sistemas antes mencionados, aunque es un extranjero que mora pero a la vez itinera.

Me interesa también analizar la colección - tanto aquella que ha sobrevivido, como la que se visibiliza en fotografías y/o se referencia en textos-, como una experiencia presente del sujeto, pero también como autor consciente que se proyecta, a partir de ella, al futuro. Así, desde ese futuro que es el hoy, aquel pasado se presenta como una construcción y elaboración memorial que busca constituirse en una secuencia de experiencias históricas en la Argentina y Paraguay, que de hecho son sólo «fragmentos eleáticamente recortados», como menciona Cortázar en el texto arriba citado.

Toda colección asume un carácter de «poder»: desde los orígenes del coleccionismo, poseer, acumular, recopilar y mostrar fue símbolo de un «poder» sobre los objetos/sujetos. «Poder» que a la vez construye conocimiento, saber, y memoria. El saber no es sólo un «don», sino que supone manejar materiales e instrumentos que hacen que ese saber se transforme en «poder», y que articule elementos en la construcción de una historia y una memoria. En este caso, las materialidades que posee/acumula/recopila De Boccard se vinculan con las regiones recorridas, cuya ocupación tardía por los Estados nacionales del Cono Sur Americano, hace de ellas espacios de particular interés en su conocimiento por parte de los mismos Estados y de su inserción al sistema capitalista mundial ${ }^{8}$.

De tal modo, en este artículo abordaré tres estratos de entrada a un intermediario cultural, los que se evidencian de modo dialógico y por ello no responden a secciones estancas de este texto. El primero habla de Louis de Boccard, sus roles, vínculos académicos y políticos y sus itinerarios en el Cono Sur Americano. La segunda escala de análisis se centra en la colección,

7 Wolf considera estos grupos como organizaciones o estructuras intersticiales, suplementarias o paralelas al sistema institucional de poderes económicos y políticos con el que coexisten o se coordinan, que distribuyen y controlan poder en competencia tanto entre ellas como con el Estado (Wolf, 1956).

8 De hecho, la historia del coleccionismo americano es fundamental para comprender los procesos por los cuales se ha producido la «apropiación» de grupos sociales considerados «primitivos», «exóticos», de sus tierras y de sus riquezas, lo cual implica reconocer las relaciones de poder entre quien colecciona y los sujetos que previamente poseían esos artefactos. 
la capacidad de De Boccard de construir artefactos y de posicionarse social y científicamente a partir de/con ellos y el interés por el registro y el coleccionismo como construcción memorial. Y la tercera, responde al rol que la visualidad tiene en la vida y los artefactos coleccionados por De Boccard: el modo en que su vouyerismo, su interés de explorador y naturalista canalizados en una "pulsión escópica»" ${ }^{9}$ lo llevaron a construir estos artefactos culturales, objetos dotados de propiedades materiales cuya dimensión significante de carácter histórico, social y colectivo actuaron en el plano experiencial apoyados en el soporte material de las obras ${ }^{10}$. Los artefactos son formas materiales que cristalizan ciertos modos de construcción visual del mundo social, que pueden asumir una función práctica, mnemónica y/o estética ${ }^{11}$.

El coleccionismo supone un papel central en De Boccard como cultural broker, que se agencia socialmente: coleccionar no sólo lo posiciona cultural y socialmente en una red científica y social, sino también promueve una diversidad de negocios y negociaciones en los que este explorador se inserta. A su vez, esos artefactos tienen poder de agencia: Alfred Gell asume que además de los sujetos sociales, los objetos están dotados de agency o capacidad de acción sobre las personas ${ }^{12}$, en tanto conllevan una carga emocional que trasladan a los sujetos. La vida social de los artefactos, que en relación a De Boccard asumen relaciones con productores de imágenes (fotógrafos, científicos, viajeros), productores de artefactos (grupos indígenas) y la misma naturaleza, genera en las relaciones entre estos objetos y De Boccard, y entre éste y otros agentes, diversas reacciones emocionales. De estos objetos, la fotografía se agencia como el artefacto que presenta un rol relacional respecto a los demás objetos y como el artefacto-medio que en De Boccard asume una relación emocional transatlántica — con sus familiares en el Viejo Mundo-y transcultural —en relación a los grupos indígenas con quienes interactúa y con los científicos, políticos y miembros de la élite argentina-.

9 Tanto en el deseo de mirarse como de mirar: «La "pulsión escópica", el deseo de mirar, se dirige primero al cuerpo propio. Es la historia de Narciso, de la que Freud hizo una metáfora de esta fascinación [...] se dirige al cuerpo propio, para retornar bajo el deseo de ser mirado. Es decir, que mirar y ser mirado son dos movimientos del mismo deseo. La posición del sujeto cambia, pero el deseo sigue siendo el mismo. Comerse con los ojos el cuerpo del otro, ser comido por la mirada de otro» (García, 2000: 161).

10 Mukarovsky, en Lizarazo, 2004: 72.

11 Para Dickie una obra es aquel artefacto al que la sociedad o un subgrupo de ella (artistas, coleccionistas, curadores, agentes de arte y otros «mediadores») otorgó el estatuto de candidato a la apreciación, a la evaluación estética (Dickie, 2005).

12 Gell, 1998. 
El corpus que analizo se corresponde con objetos, documentos e imágenes que hoy se encuentran diseminados en distintos lugares de América y Europa, con situaciones diferenciales de acceso. Todo ello se va describiendo y desentrañando a lo largo del artículo. Sólo por mencionar algunos aspectos, el corpus está constituido por álbumes de fotografías y de postales, objetos coleccionables, animales que Louis de Boccard embalsamaba y exponía en su estancia (que se encuentran representados en las imágenes o referenciados en los textos), y numerosos libros, diarios y almanaques del profesor De Boccard, mencionados en ocasiones como Journal Quotidien Illustré de Louis de Boccard, que compilaba en anuarios ${ }^{13}$. Estos anuarios contenían no solamente información minuciosa de su contabilidad personal y bienes, sino también referencias a visitas recibidas y realizadas, a viajes de los que guardaba documentación diversa: tickets de entrada a eventos, invitaciones, postales recibidas, pasajes, etc. Fueron escritos al principio en francés y desde 1930 en español. Comenzaron a realizarse hacia 1908, con aparentes cortes, y reiniciados, según palabras de De Boccard, hacia 1922 durante una estancia en Asunción ${ }^{14}$. Las cartas que se conservan son especialmente las enviadas a su familia, que se encontraba en Suiza. Resulta significativo que tras los 61 años de vida americana estas cartas fueran numeradas por el mismo De Boccard, y esta numeración constituía una referencia mediante la cual se comunicaba con su familia, remitiendo al número de carta cuando quería hacer hincapié sobre un tema tratado. Ello hace suponer que conservaba copias de todas las cartas enviadas, que durante algunos periodos eran realizadas diariamente.

\section{ITINERARIOS FRAGMENTARIOS EN EL CONO SUR AMERICANO}

Louis de Boccard nació en el cantón suizo de Fribourg el 8 de mayo de 1866 y murió en Areguá, Paraguay, el 30 de abril de 1956. Arribó a Argenti-

13 Si bien tiene algunos elementos de un scrapbook, se escapa de éste en cuanto lleva también las cuentas personales con ingresos y egresos diarios.

${ }_{14} \mathrm{Al}$ inicio del Journal 1925 (Colección Monges), Boccard dice haber comenzado estos diarios en mayo de 1922 como «journal de la vie quotidien». En este caso, da a entender que antes no había realizado estos diarios, sin embargo, contamos con un ejemplar de 1910 que aparece como el n. ${ }^{\circ} 30$ de los libros-anuarios (Colección Monges). Por otro lado, en el libro Libro 1930, Colección Monges, expresa: «Este libro diario es el N50, es decir que desde hace 50 años, a la edad de 14 años, cuando mis queridos padres a ejemplo de ellos me hicieron empezar a escribir cada noche antes de acostarme mis impresiones y todo lo que yo había hecho en el día; he seguido siempre esta loable costumbre que me ha prestado grandes servicios durante mi vida». El 1 de enero de 1947 nuevamente recuerda en el Libro 1947, Colección Monges, el inicio de esta práctica, diciendo que llega al libro 62. 
na en 1889, donde comenzó a trabajar en un establecimiento quesero cerca de Bragado, provincia de Buenos Aires, que tenía por objeto la fabricación de un queso similar al gruyere. El recorrido por el campo bonaerense le dio un panorama del mismo, de las costumbres y labores, como también relaciones con otros suizos localizados en la región. Desde su llegada a Argentina, comenzó a registrar fotográficamente ciudades, escenas en el campo, personajes y familiares.

Casi al año de haberse establecido en Argentina, ingresó contratado como conservador/preparador anatómico del Museo de La Plata ${ }^{15}$. Como muchos otros viajeros-exploradores en un contexto de gran movilidad ${ }^{16} \mathrm{y}$ de creación de puestos de trabajo en diversas reparticiones del Estado argentino, se vinculó en este caso con una institución pionera de la ciencia argentina ${ }^{17}$. De Boccard sólo estuvo unos pocos años en dicha institución ${ }^{18}$, y es prácticamente desconocido por la historiografía argentina su papel en la misma ${ }^{19}$; en ese tiempo, según la escasa bibliografía y artículos periodísticos tardíos, participó de algunas expediciones a la Patagonia con el director del Museo, Francisco Moreno ${ }^{20}$.

Hacia 1894 estaba radicado en Gualeguay (Entre Ríos), donde permaneció hasta fines de siglo, dedicándose a la práctica de la fotografía comercial y desempeñando también roles de taxidermista. Es en este contexto cuando

15 Una foto de su laboratorio en La Plata, con el epígrafe «Mi Laboratorio en La Plata, 1890» se encuentra en un álbum sin título que contiene imágenes de distintos momentos de su vida y en diferentes espacios, Colección Machuca.

16 Regresó a Suiza en numerosas ocasiones para visitar su familia. En 1892 realizó el primer viaje, y al volver a Buenos Aires - travesía que se extendió del 30 de enero al 20 de febrero de 1893-, documentó fotográficamente escenas y personajes del buque de vapor Paraguay, como también la rada de Montevideo y el puerto de Buenos Aires. Estas imágenes se encuentran en el Album de Familia, Colección Machuca.

17 El Museo de La Plata (capital de la Provincia de Buenos Aires, Argentina), había sido creado en 1884, dos años después de su fundación oficial. Sobre el rol del Museo de La Plata en sus orígenes, véase Farro, 2009.

18 No podemos precisar cuántos años, pero en 1894 lo encontramos radicado en Gualeguay (Entre Ríos).

19 Farro, que ha estudiado el origen de las colecciones del Museo de la Plata y el rol de naturalistas viajeros en el mismo, no consigna la presencia de De Boccard en esta institución. Pone de manifiesto, sin embargo, la gran cantidad de viajeros y científicos que fueron contratados por la misma a fines del siglo XIX, o que ofrecían colecciones al Museo. Farro, 2009.

${ }^{20}$ De Courten, 1987: 143. Resulta significativo que no se haya encontrado mención de su participación en los diferentes viajes que Moreno realizó a Neuquén, Río Negro y la Patagonia sur. Es por ello que nos permitimos poner en duda tal participación, que ha sido reproducida en varias de las notas periodísticas que ya avanzado el siglo XX se le hicieran a De Boccard. 
comenzó a perfilar la posibilidad de convertirse en propietario de tierras ${ }^{21}$, adquiriendo en 1897 una estancia ${ }^{22}$, que denominará La Mirelia, nombre de su hija ${ }^{23}$. Esta adquisición derivaría del dinero familiar que invierte en Argentina, luego de convencer a su familia de que este país «no es más salvaje» ${ }^{24}$. Sin embargo, su rol como propietario-ganadero no le dio las rentas esperadas para devolver el préstamo, lo que sumado a la separación de su esposa Inés, hará que hacia 1900 se establezca en Buenos Aires.

Las expediciones serán una constante en la vida de De Boccard, y una fuente de recursos coleccionables y vendibles. Radicado en Gualeguay, lo seducen el norte argentino y el Paraguay, realizando en 1898-99 una expedición por el río Iguazú 25 , recorriendo la antigua zona jesuítica junto a su primo Raymond de Boccard y Tehóphile Pictet. En 1900, ya radicado en Buenos Aires, realiza una misión diplomática a $\mathrm{Chile}^{26}$ y una expedición a las Cataratas del Iguazú, acompañando a ministros de Francia, Suiza y Austria: esta vinculación con la diplomacia se sustentó en un trabajo para el Ministerio de Asuntos Exteriores de Argentina, y los viajes realizados conjugaban su rol diplomático con el interés exploratorio y de coleccionista, a la vez que visualizaba la experiencia, confeccionaba álbumes y editaba postales de estos viajes.

Tras las expediciones que supuestamente realizó al sur argentino junto a Moreno, y merced a vínculos establecidos, participará de otras de carácter

${ }^{21}$ En una carta enviada a sus padres y hermanos, hace alusión al hecho que el campo le permitirá desarrollar mejores negocios que Buenos Aires. Carta a sus padres y hermanos, Gualeguay, 23/12/1894, Colección Théo Savary.

${ }_{22}$ No conocemos el lugar de la estancia, sólo menciona una distancia de 4 horas a caballo desde Gualeguay.

${ }^{23}$ Louis se casó con Inés Windels, con quien tuvo dos hijos: Mirelia y Alfonso. Su hija murió de un accidente con un caballo en 1919. Su hijo permaneció en el Paraguay, donde murió en 1966, sus descendientes se encuentran en la localidad de Areguá.

${ }^{24}$ Carta de Louis de Boccard a sus padres y hermanos, Gualeguay, 31/3/1897, Colección Théo Savary. En relación a la compra de la estancia, no queda claro en la documentación si fue propiedad exclusiva de De Boccard, o si la compartió con el anterior propietario de la misma, Pythoud. También la documentación habla de personas que aportaban animales y que tal vez fuesen socios de la empresa.

25 Sobre esta expedición De Boccard confeccionó dos álbumes, uno en español y otro en francés. El álbum en español se titula Viajes y Exploraciones a los Territorios del Alto Paraná, Paraguay, Misiones y Brazil, 1898-1899 y se encuentra en la Colección Savary.

${ }^{26}$ De este viaje, Boccard hizo un álbum fotográfico que tituló Viaje a los Territorios del Neuquén, Cordillera del Sur y Chile. Enero-mayo 1900 y que se encuentra en la Colección Monges. Según sus propias palabras, su función como «asesor» del Ministerio de Relaciones Exteriores de Argentina, fue evaluar la situación en Chile ante litigios internacionales entre estos dos países. 
privado a la misma región ${ }^{27}$. Sobre la expedición Anchorena - que tuvo gran atención en la prensa de la época y fue estudiada por la historiografía ${ }^{28}$ - el rol de De Boccard no ha sido reconocido. Existen fotografías, - algunas de ellas publicadas en Suiza en un pequeño álbum junto a otras de expediciones al norte- - y también numerosas cartas enviadas a su familia en Suiza, donde De Boccard se ubica como el guía general de una expedición de amplio reconocimiento en la prensa y la élite porteña. Se posiciona como un personaje central en el armado y ejecución de la expedición, en la que menciona la participación de un fotógrafo:

... tengo la responsabilidad de todo: la dirección del personal, de los carruajes, excursiones a caballo y mulas; los peones (guías y domésticos), de la fotografía; de las aves de taxidermia y animousse (?); preparar la jornada de viaje, hacer un informe para el Ministro de Colonias sobre las tierras y países que cruzamos; preparar medicamentos; llevo una verdadera farmacia conmigo... ${ }^{29}$

Las experiencias relatadas en numerosas cartas sobre esta expedición, más allá del relato del itinerario, de las relaciones entre los expedicionarios, es asumida por el mismo Boccard como una experiencia diferente por tratarse de un «millonario» quien la lleva adelante: «Es agradable viajar con los millonarios que no se preocupan por los gastos; qué diferencia de este viaje con el que hice con Raymond» ${ }^{30 !}$

Tanto ésta como expediciones posteriores realizadas a otras regiones se constituyen, junto a las imágenes, en experiencias extraordinarias de su vida americana que contrastan con otros períodos en que sus affaires - emprendimientos inmobiliarios y ganaderos-, no le dieron el resultado esperado. Asentado en Buenos Aires desde principios de siglo, fueron esos negocios a los que se dedicó, con apoyo de sus padres ${ }^{31}$. Hacia 1916 lo ubicamos itinerando periódicamente entre Buenos Aires y La Colina, en la provincia de

27 En particular la Expedición Anchorena. Véase Anchorena, 1902: 3.

28 Masotta, 2009.

29 Carta de Louis de Boccard a sus padres. Rawson (Chubut), 20 de diciembre de 1901, Colección Théo Savary (traducción Mariana Giordano).

30 Carta de Louis de Boccard a sus padres, Lago Nahuel Huapi, 20 de Marzo de 1902, Colección Théo Savary. Al aludir al viaje con Raymond se refiere a la Expedición de 1898-99 al Alto Paraná, Misiones, Paraguay y Brasil.

31 En 1905 lo encontramos residiendo en la Calle Cramer 1845 y en 1907 en Sucre 2648, Belgrano, Buenos Aires, pero en las dos primeras décadas del siglo XX realizó varios viajes a Europa: concretamente en los años 1903-1904, 1909 y 1913. Durante alguno de ellos estuvo en Dakar. Por otro lado, su hija Mirellia residía por esos años en Inglaterra y en Suiza, y se advierte en una postal que en 1919 su podre se disponía a visitarla. 


\section{IMAGEN 1. LUGARES DE RESIDENCIA Y ALGUNAS EXPEDICIONES REALIZADAS POR DE BOCCARD ${ }^{32}$}

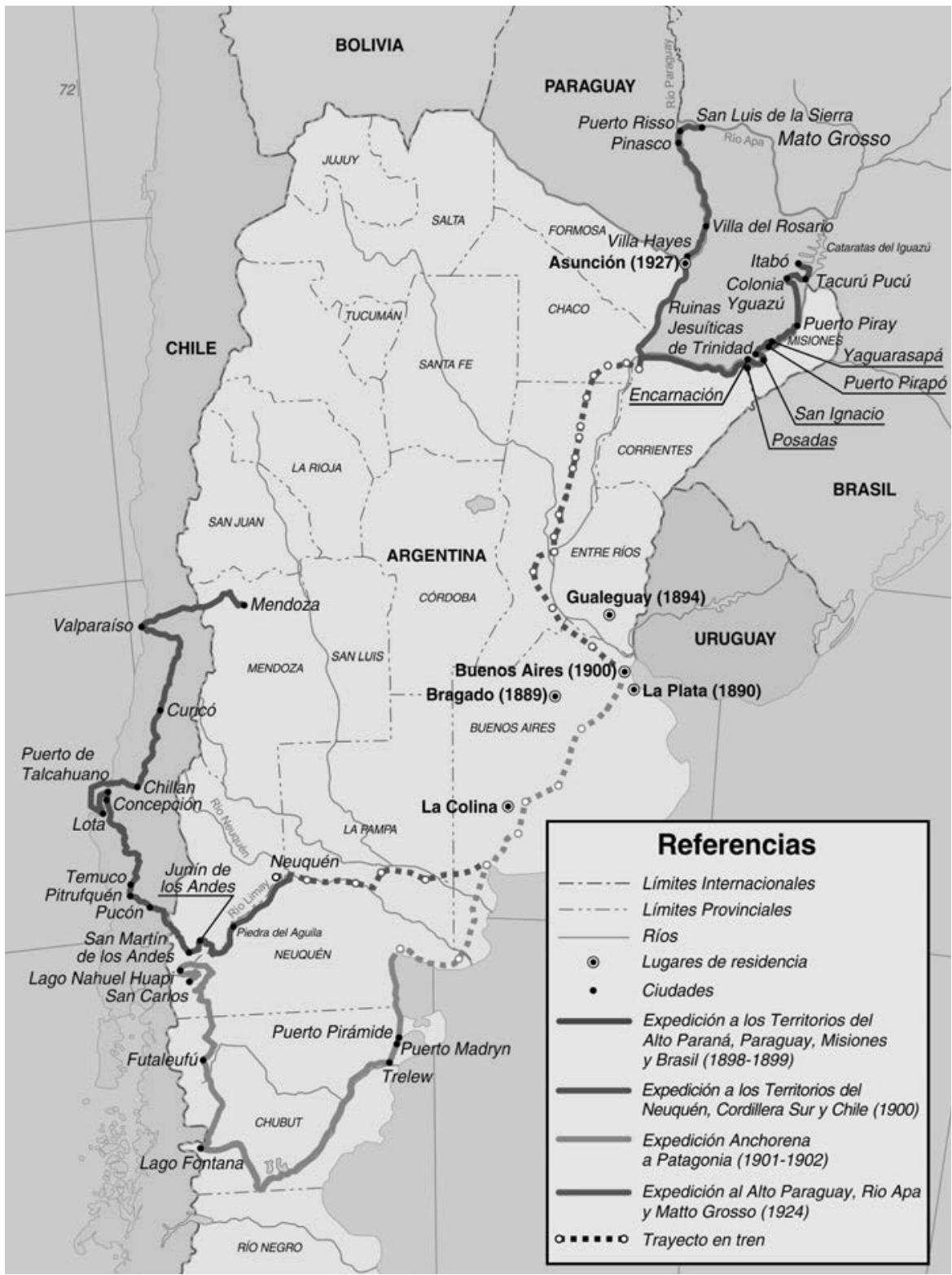

32 Mapa elaborado por Cristian Touilleux.

Revista de Indias, 2019, vol. LXXIX, n. ${ }^{\circ} 275,235-263$, ISSN: 0034-8341

https://doi.org/10.3989/revindias.2019.008 
Buenos Aires, donde se inició en el trabajo ganadero su hijo Alphonse. Las narrativas de esta época revelan una profunda pesadumbre personal, una desazón por la mala relación con su hija, y preocupaciones por la guerra en Europa, donde había ido al comenzar la guerra. Si consideramos toda su producción y colección como una autobiografía, podemos decir que las cartas de esta época ponen de manifiesto un sujeto descentrado de sus intereses naturalistas iniciales, apesadumbrado por sueños frustrados, donde el interés científico de fines del siglo XIX y principios del XX se anula. Recién con expediciones posteriores a Paraguay, se reactivará ese perfil, como también la red de relaciones políticas que llevará adelante.

Se desconoce el número de viajes realizados a la región del Gran Chaco, pero en particular se orientaron al Chaco paraguayo; de las grandes expediciones realizadas Alto Paraguay, Río Apá y Matto Grosso (1924). Su rol de «explorador» es lo que explota en la difusión de las imágenes: la postal le sirvió, en este sentido, para difundir ese rol, haciendo circular de este modo un producto visual de carácter exotista incluso para las metrópolis sudamericanas. Reside y transita entre Buenos Aires y Asunción. En 1932 radicó definitivamente en Areguá, Paraguay, donde adquirió una estancia de 289 hectáreas, a la que también denominó La Mirelia. Desde ese lugar, sus expediciones por el Chaco paraguayo serán más frecuentes.

\section{BROKER Y COLECCIONISMO}

De Boccard se mueve en un ámbito transcultural. Su status de inmigrante lo llevó a relacionarse con otros inmigrantes suizos en Buenos Aires y Santa Fé, pero a la vez logró construir relaciones de amistad «instrumental» ${ }^{33}$ y camaradería con científicos, políticos y personajes de la élite argentina, que son recurrentemente mencionados en sus textos tempranos y (re)mencionados insistentemente en sus textos tardíos, que asumen el carácter de memorias de una (auto) construcción.

El de cultural broker es semejante al rol que Ares Queija y Gruzinski dan a ciertos mediadores culturales a los que definen como «agentes sociales que, desde una posición a menudo liminal y a caballo entre culturas, favorecieron las transferencias y el diálogo entre universos aparentemente incompatibles, elaborando mediaciones muchas veces insólitas y contribuyendo así a su articulación y a la permeabilización de sus fronteras» ${ }^{34}$. Es el papel que, de

\footnotetext{
33 Wolf, 1956.

34 Ares Queija y Gruzinski, 1997: 10.
} 
algún modo, también alude Mills al referirse a «movilizadores culturales» de procesos y personajes, concepto que fue aplicado especialmente en los estudios coloniales ${ }^{35}$, pero que creemos adecuado en estos ámbitos aún fronterizos de las culturas americanas a fines del siglo XIX y principios del XX. Esta articulación/mediación/movilización de un agente social como De Boccard, y tal es una de las hipótesis de este trabajo, se funda no sólo en ese «fluir» por el espacio geográfico e intercultural, sino también en la construcción de redes de relaciones sociales, políticas y académicas que un personaje «secundario», casi desconocido de la historia política y de la ciencia argentina, ha tejido entre políticos, hombres de ciencia, población local, viajeros-exploradores y diplomáticos, principalmente en Argentina y Paraguay, con algunas incursiones en Chile. Pero también ocupa ese rol, por la capacidad de exponerse y (re)presentarse a través de diversos circuitos y medios, como un explorador y mediador de temas políticos, por su estrategia de ocupar espacios que las instituciones inexistentes debieran haber constituido. La producción visual y artefactual de De Boccard revela paradójicamente el «derecho a ver» como dispositivo de conocimiento a la vez que de poseer aquello que se (re)presenta a partir de un discurso compacto de la modernidad: fotografías propias y colecciones de imágenes de otros viajeros, exploradores y expedicionarios, que podrían constituirse en los primeros artefactos de análisis. Pero muchas de ellas se construyen en nuevos artefactos como son los numerosos álbumes confeccionados, que revelan un afán por el coleccionismo como modo de conocimiento y de posesión, pero también la necesidad de construir una narrativa de la experiencia americana: cada una de las expediciones que realiza De Boccard tiene como resultante uno o dos álbumes, versiones de la misma experiencia en diferentes idiomas (español y francés), pero también juega con la imagen poética en sus numerosas cartas y descripciones étnicas.

Los animales, especies vegetales, objetos, artesanías, etc., que De Boccard iba recogiendo en sus exploraciones por el Gran Chaco formaron parte de fondos de otros coleccionistas, pero también conformó su propia colección. Las fotos de su casa en Areguá, Paraguay, exponen espacios que se articulan con la idea de un gabinete de curiosidades ${ }^{36}$ en una etapa tardía - fines del

35 «... un amplio juego de procesos transformadores que comienzan cuando esta gente, ideas o materia se mueve entre distintos miembros o usuarios en la sociedad colonial emergente de Hispano América», Mills, 2004: s/f.

36 Sobre el concepto y la práctica de coleccionar curiosidades que se inició en el siglo XV y se consolidó en el siglo XVI, véase, entre otros, Boëtsch, 2012. Martin y Bleichmar, 2015. Bleichmar y Mancall, 2016. Boëtsch afirma que a principios del siglo XVI los gabinetes de curiosidades clasificaban sus contenidos en cuatro principales categorías, que nos pa- 
siglo XIX y principios del XX - de construcción de estos espacios de guarda y exhibición. De Boccard fue construyendo su propio gabinete de curiosidades con objetos no sólo coleccionables, sino también intercambiables, a partir de sus viajes y con intereses que muchas veces se basaron en la posibilidad de intercambio o comercialización de objetos ${ }^{37}$. También sus anuarios, muchos de los cuales conservan sus descendientes en Paraguay, siguen esta idea del coleccionismo vinculado al universo de las curiosidades a la par que se mezclan con lo que podría ser un diario personal y un registro de sus emprendimientos agropecuarios. De Boccard colecciona insistentemente, sin discriminar: mariposas, hojas, insectos, grandes animales disecados, tickets de entrada a un teatro o de acceso a un tren, cartons, collages, silouettes, postales, cajas de fósforos, tickets del Aeródromo de Longchamps, cueros de animales, fotografías de personajes ilustres, de su familia, de sus campos. Principalmente, conserva aquello que remite a su vivencia americana y que para un espectador europeo se incluiría dentro de lo «exótico» del gabinete de curiosidades, pero también hay rastros de sus viajes a Europa: las etiquetas de productos europeos y americanos del siglo XX, junto a postales coloreadas constituyen una importante colección de estos artefactos culturales.

Estas colecciones fueron conformadas a través de diferentes estrategias: con las imágenes fotográficas obtenidas por el mismo De Boccard, y con las que conformó gran cantidad de álbumes, pero también con fotografías de otros viajeros y exploradores que en muchos casos articulaba con las propias en algunos de estos álbumes. La trama narrativa que construye con ellas y con todo el universo objetual-artefactual y textual constituye un «espacio biográfico» ${ }^{38}$ que en el esquema moderno ubicaba al sujeto como centro de la escena ${ }^{39}$. Es quien ha visto, vivido, oído, una aseveración de la experiencia/memoria personal — que no deja de ser colectiva asumiendo la idea de

rece importante mencionar por la permanencia de alguna de ellas en el siglo XIX: naturalia, que incluía criaturas y objetos naturales; exótica, que comprendía plantas y animales; scientífica, de instrumentos científicos; y artificialia, de objetos manufacturados como medallas y obras de arte (Boëtsch, 2012: 78).

37 Appadurai (1991: 20) plantea que el comercio o intercambio basado en el «deseo» sobre un objeto, es la base del valor de ese objeto.

38 Arfuch, 2002.

${ }^{39}$ La historicidad del esquema moderno de fines del siglo XIX suponía una experiencia del tiempo y del espacio positivo del sujeto. Luego de las independencias latinoamericanas, los viajes y las exploraciones en la amplia geografía americana tuvieron, en parte, ese interés del sujeto de construir su propio espacio biográfico. De Boccard se presenta como un sujeto moderno-tardío en las exploraciones de los espacios también tardíamente incorporados a la modernidad capitalista. 
IMAGEN 2. TAPA DEL LIBRO DIARIO DE 1942

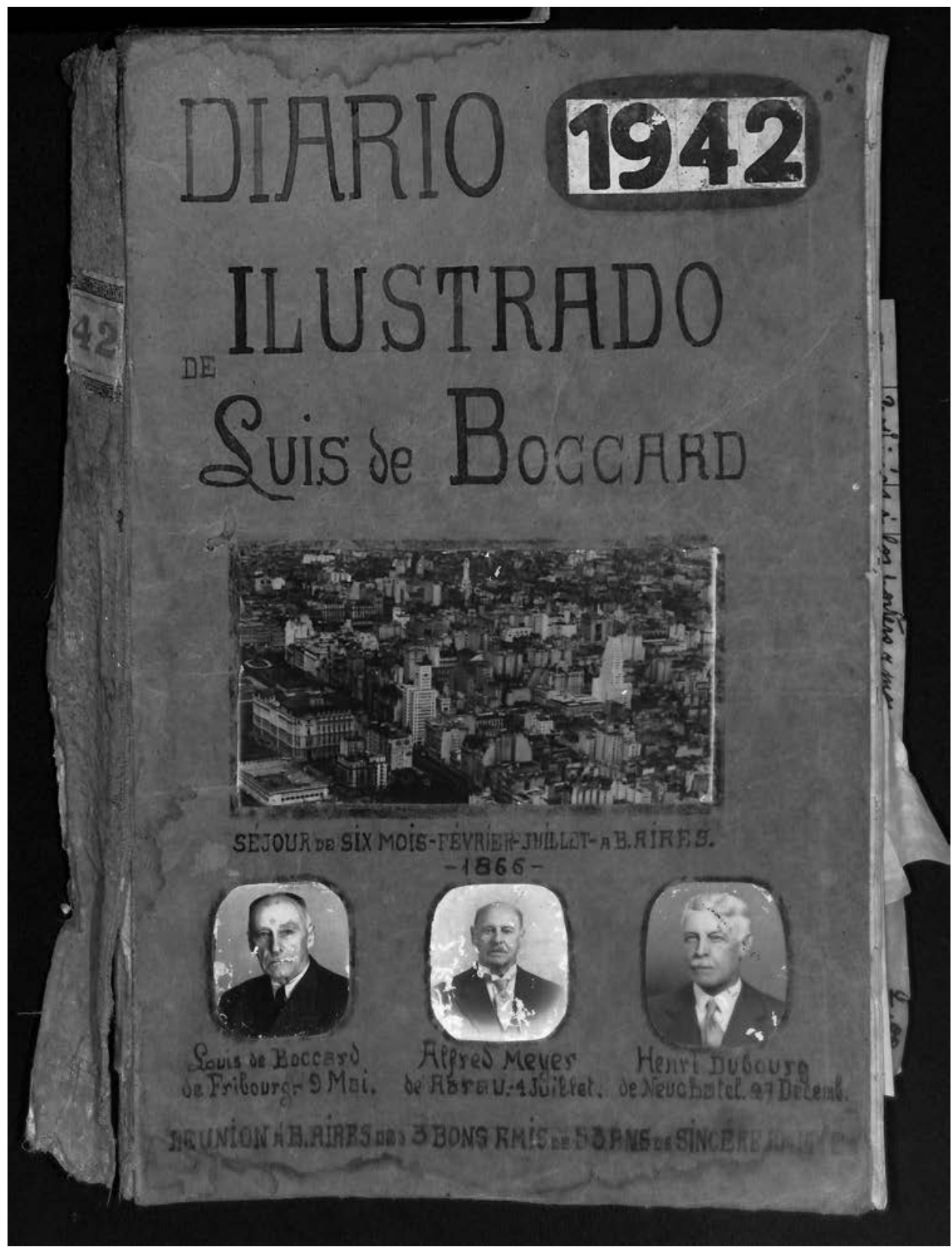

Colección Monges.

Revista de Indias, 2019, vol. LXXIX, n. ${ }^{\circ}$ 275, 235-263, ISSN: 0034-8341

https://doi.org/10.3989/revindias.2019.008 
Halbwachs ${ }^{40}$ de que un sujeto recuerda en un medio social-, a través de indicios, huellas, fragmentos que revelan una inquietud desafiante tanto a un presente/instante/fugaz como a un futuro/ausente/memorial. Pero que visto desde su producción constituye un gran rompecabezas autobiográfico que propone en lo objetual, la imagen y el texto escrito una resistencia a la desaparición. La dimensión memorial que supone el coleccionismo, $-\mathrm{y}$ que desde esos momentos autobiográficos en De Boccard podrían entenderse como registros aleatorios-, sin embargo, son tramas significantes que nos interpelan sobre el viaje, la transculturalidad, la ciencia, la política, la alteridad y la memoria. Si bien en su conjunto esta colección conlleva una narrativa y una temporalidad propia de los «grandes relatos» modernos donde se superponen y se solapan historias y representaciones, en su particularidad, cada objeto, artefacto, imagen, texto, son micro-relatos que constituyen espacios discursivos significantes, como lo es también la misma trama en la que se insertan.

Asimismo, este coleccionismo se relaciona con el rol de De Boccard de cultural broker, con la posibilidad de obtener a través de los bienes coleccionables y vendibles un ingreso económico, con una personalidad romántica y atormentada, temerosa del tiempo y la distancia. Angustiado por la necesidad permanente de reconocer ante su familia cierto «éxito» en tierras americanas, que la correspondencia con sus padres pone en evidencia: protegido por su madre y acusado por su padre por los emprendimientos frustrados en América, que requerían muchas veces envío de dinero por parte de su familia europea. Una carta de su hermana Antoinette de 1891 plantea justamente esa posibilidad de su hermano Louis de convertirse en millonario ${ }^{41}$, mientras que cuatro años después Louis se encontraba en Gualeguay, pensaba dedicarse a trabajar como fotógrafo y taxidermista, estimando que el campo sería mejor que mantenerse en la ciudad. Se embarca entonces en exploraciones por la zona, demanda a su padre vender propiedades para comprar tierras en la zona entrerriana, que ya no es más un "país salvaje» ${ }^{42}$. De Boccard siente temor mientras el tiempo transcurre sin los éxitos que esperaba, y que sólo el «rescate» de los objetos investidos por él de valor, atenúa el temor: siguiendo a Baudrillard, el impulso coleccionista busca «ejercer control sobre el mundo exterior» que lo lleva a «desplazar el tiempo real» ${ }^{43}$.

40 Halbwachs, 1992.

41 Carta de Antoinette de Boccard a Louis de Boccard, Locarno, 28 de febrero de 1891, Colección Théo Savary.

${ }^{42}$ Carta de Louis de Boccard a sus padres y sobrinos, Gualeguay, 31 de marzo de 1897, Colección Théo Savary.

43 Baudrillard, 1994: 7-24. 
La distancia espacial con sus orígenes plantea cierta nostalgia, que es, sin embargo, sopesada con la valoración positiva de la distancia cultural en la que se inserta. Este viajero, peregrino, es casi un flâneur ${ }^{44}$ convertido en explorador. En tierras americanas observa, valora, escribe, transita tanto entre los ambientes políticos y académicos de Argentina y Paraguay como entabla relaciones con grupos indígenas y mestizos. Sobre todos ellos se refiere, tanto en imágenes como en sus cartas o en sus diarios de viaje o anuarios. Así, su comportamiento como viajero conserva casi un siglo después muchos de los elementos románticos de principios del siglo XIX. Sin embargo, si tomamos la caracterización del sociólogo polaco Bauman, De Boccard se encontraría en la intersección entre dos tipos de viajeros que reconoce: el peregrino y el paseante-flâneur ${ }^{45}$.

Angustia, temor y distancia hacen que en ocasiones sus experiencias relatadas por él mismo —o por la prensa a la que se presentaba como explorador, profesor y científico, indistintamente-, discurran en un límite borroso entre la verdad y la verosimilitud. Por momentos, sus escritos muestran una participación activa en círculos académicos y políticos con ciertos índices de grandilocuencia como justificativo familiar de sus fracasos económicos; pero a la vez, la correspondencia que intercambia con académicos, los viajes realizados con diplomáticos - a los que nos referiremos luego-, no lo ubican como un mero «charlatán» ${ }^{46}$, valoración en la que podría entrar De Boccard

${ }^{44}$ El concepto de flâneur, que Baudelaire describe a fines del siglo XIX, hacía referencia a un sujeto curioso, errante y observador de las ciudades, «esas almas en pena que buscan un cuerpo» (Baudelaire, 1954: 296). Baudelaire realiza una asociación del flâneur con el voyeur (viajero). En este caso, De Boccard es un flâneur no sólo de las ciudades, sino que su curiosidad, errancia y observación, se proyectan a pequeñas ciudades y al ámbito rural. Pero sin duda, coincide con este personaje en el valor de la observación y la itinerancia de la mirada, y en el hecho de que en la construcción de esa mirada, también delinéa su «yo».

45 Bauman, 1997: 136-159. Al tratar los libros de viaje, Bauman realiza una clasificación del viajero, atendiendo a la intencionalidad y comportamiento durante sus desplazamientos. Los tipos de viajero que establece son: el peregrino, el vagabundo, el turista y el paseante (flâneur). El peregrino se encuentra siempre a la búsqueda de algo que se encuentra en otro lugar, por lo que su desplazamiento es continuo. El vagabundo es un nómada que se traslada constantemente, sus necesidades lo impulsan y le señalan el rumbo, que nunca es fijo, por lo que tiene una libertad total de movimiento. El turista tiene un lugar al cual retornar luego del viaje, y su trayecto lleva una intención explícita. El paseante o flâneur sale a descubrir escenas, los países y paisajes son pinturas en las que se entremezclan el parecer con el ser y las describe así como él las ve, como superficies o láminas de un libro

46 Lo entendemos desde en el sentido amplio de «charlatán» y no sólo en el atribuido a los que prometen remedios para enfermedades incurables (Podgorny, 2015) o a soluciones sobrenaturales de ciertos «males». En este sentido amplio, el charlatán también convence a sujetos políticos e interactúa entre la sociedad civil y la académica, consiguiendo beneficios 
cuando en muchas cartas presenta escenarios lejanos al vivencial, y principalmente al construir una vinculación filial con Juan Domingo Perón ${ }^{47}$.

\section{Álbumes y NARRATIVA VISUAL-TEXTUAL}

Si bien muchos viajeros, expedicionarios y científicos produjeron materiales visuales, interesa en este caso analizar el juego de relaciones y de construcciones visuales y artefactuales desde el rol de cultural broker que pareciera definir en primera instancia a De Boccard: naturalista/científico del Museo de la Plata, agente secreto del Estado Argentino, explorador y empresario ganadero, no sólo desempeñó diversos roles, sino que también representó visualmente y constituyó colecciones etnográficas y fotográficas propias a la vez que abonó objetos a instituciones o expediciones recolectoras argentinas.

La fotografía como evidencia es el elemento central en la colección de De Boccard. La utilización de la fotografía no sólo le sirvió como registro de especies naturales, animales, escenas de caza, vida familiar y social, sino también, como sustento de vida en los momentos en que se frustraban sus negocios inmobiliarios o sus emprendimientos ganaderos. La colección fotográfica de De Boccard está compuesta por una gran cantidad de álbumes hasta el momento he localizado trece de fotos y uno de postales-, a algunos de los cuales hice referencia al tratar los itinerarios de viaje y las expediciones, ya que responden a tales experiencias. A ello debe sumarse un álbum de fotos publicado en Suiza, de pequeño formato, titulado Unas Vistas de las Expediciones y Viajes del explorador de Boccard en la América del Sud ${ }^{48}$, que contiene doce imágenes de sus expediciones al Alto Paraná, Gran Chaco y Patagonia. Asimismo, existe una colección de cerca de 600 postales, tanto de su familia, como postales urbanas o de sus expediciones. A ello se suma una cantidad considerable de fotografías pegadas en los Anuarios a los que ya me

\footnotetext{
de tales intervenciones para las que no siempre está preparado, ya sea en cargos o en dinero o en conocimiento de sus fundamentos. Y siempre se presenta como capacitado para ciertas funciones o actividades, legitimadas por pasos furtivos o por ámbitos científicos o académicos. La fantasía cobra un rol significativo en estos charlatanes, que construyen historias para esa autolegitimación.

47 Se trata de una carta incompleta, donde De Boccard menciona esta relación filial, La Mirelia, Paraguay, 12 de diciembre de 1955, Colección Théo Savary.

48 De Boccard, Société des Arts Graphiques, Sècheron, Genève, s/f. Un ejemplar de este álbum fue consultado en el Museo Etnográfico «Juan Bautista Ambrosetti», Universidad de Buenos Aires, Buenos Aires.
} 
referí, y un álbum que, aunque no contiene fotografías, pone en evidencia su interés en conformar este tipo de artefactos: se trata de un Album de Cartons-collages $^{49}$, con objetos de este tipo tanto europeos como de Sudamérica.

No es intención de este artículo analizar cada álbum en su especificidad, sino atender a éstos en tanto artefactos que presentan una dimensión visible (imagen) y una dimensión enunciable (palabra-texto), indagando también en la interacción entre ambas. De tal forma, se consideran las posibilidades, efectos y motivaciones de la relación entre imagen y palabra, o lo que es lo mismo, el grado de equivalencia, (in)dependencia y colaboración entre ambas. Asimismo, la circulación que algunas fotografías han tenido y que el mismo álbum se muestra como repositorio de tal circuito.

Los álbumes de familia se conforman tanto por uno titulado Album de Famille $^{50}$ iniciado en Europa, como por otros tres que registran los momentos de asentamiento en estancias: Album de la Province d'Entre Rios; Rep. Argentine et de l'estancia La Mirelia, Gualeguay-Entre Rios ${ }^{51}$ y Album de la Estanzuela "La Mirelia», Areguá, Paraguay. Adquirida en 1932 por Luis V. de Boccard ${ }^{52}$ al que luego incorpora los registros de su arribo al puerto de Buenos Aires, imágenes propias de la ciudad como otras del fotógrafo Samuel Rimathé. Muchas de las fotografías incorporadas en éste y otros álbumes no siguen una cronología, sino que se intersectan con personajes, episodios que en la memoria autobiográfica que estos álbumes suponen, y en los cuales el sujeto articula significativamente. Un álbum interesante es el que Nicolas Savary ha denominado el Gran Album, ya que carece de nombre: reúne mapas, planos, fotografías de La Plata y Buenos Aires, espacios rurales, personajes típicos (muchos de ellos obtenidos por Rimathé), escenas gauchescas, entre ellas fotografías de la Sociedad Fotográfica Argentina de Aficionados, como también reproducciones de grabados de escenas indígenas en territorios imaginarios o de malones con una estética romántica, junto a un grabado del cruce de los Andes de San Martín. En su conjunto, este álbum reúne imaginarios urbanos con escenas románticas de una mirada basada en un cierto encantamiento de fines del siglo XIX sobre un territorio y una sociedad que se pretende desconocida, siendo estas imágenes un modo de articular imaginariamente fragmentos hilvanados en el álbum.

49 Colección Monges.

50 Colección Machuca.

51 Idem. Si bien este álbum trata de su período en esta estancia entrerriana, las últimas cinco páginas contienen fotografías de Bragado, el primer lugar donde se instala una vez arribado a la Argentina.

52 Colección Machuca. 
Los álbumes de los viajes y expediciones, donde él se presenta como «explorador» revisten un carácter singular en la narrativa visual y textual (epígrafes y en ocasiones diario de viaje) como en la individualidad de cada fotografía. Pero a la vez atendemos a que el álbum es un artefacto cultural, como lo es cada imagen que en él se encuentra. Una de las primeras expediciones de las que conformó un Album es la realizada en 1888-89 al Alto Paraná, Paraguay y Brasil, junto a su primo Raymond de Boccard y Tehóphile Pictet: el itinerario de viaje se encuentra documentado sincrónicamente, según el recorrido del viaje: poblados (Posadas y Encarnación), ruinas jesuíticas, estancias, campamentos, saltos, ríos, márgenes del río Uruguay de Paraguay y Argentina, vistas de las cataratas del Iguazú, y numerosas imágenes con los indígenas. Es el único álbum que contiene un texto de carácter etnográfico, titulado «Indios cainguas». Su narrativa mezcla elementos románticos con etnográficos. El mismo encuentro con los indígenas se revela como un «contacto» ${ }^{53}$ transitorio, pero que se muestra significativo en su experiencia y por ello lo narra, en los que la fotografía nuevamente asume un rol memorial y autobiográfico, en uno de sus primeros textos escritos en español:

Navegaba a la altura del río Hocoý, costa brazilera (sic), cuando encontré en las orillas un ser medio desnudo, que primeramente tomé para un indio, pero que resultó ser un Alemán que casi se había olvidado de su idioma maternal. Este hombre vive desde doce años en la Tribu; primeramente en calidad de prisionero, pasando después de hechos heroicos a ser segundo Cacique, y que me indujo a ir a visitar estos Indios. Tras diez horas de marcha en plena selva virgen, avistamos la «Toldería», donde ni bien hubimos llegado me vi rodeado por los habitantes que salían todos a verme como a un bicho raro. Mi presentación al Cacique revistió el carácter de una gran ceremonia. Después de cuatro días de permanencia entre ellos y tras interminables parlamenteos, merced al lenguaraz alemán y sobre todo a los regalos que les hize (sic), conseguí persuadirlos a que se dejaran retratar y vestir un poco para el caso... ${ }^{54}$

53 Pratt denomina «zona de contacto» al «espacio de encuentros coloniales, al espacio en que pueblos geográfica e históricamente separados entran en contacto y establecen relaciones duraderas» (Pratt, 1997: 26). A los viajeros-escritores que en el siglo XIX, después de los movimientos independentistas, recorren Hispanoamérica, Pratt los denomina «la vanguardia capitalista» (Ibidem: 259). Boccard asume algunos caracteres de unos y otros. Si bien no entra en contacto permanente con los espacios culturales y geográficos que recorre en una primera instancia, lo hará con posterioridad, pero a la vez, su inserción en estos ámbitos tendrá muchas de las características de la trayectoria neocolonial a la que se refiere Pratt respecto de la «vanguardia capitalista».

54 De Boccard, «Indios cainguas», Album Viajes \& Exploraciones a los Territorios del Alto Paraná, Paraguay, Misiones y Brazil 1898-1899, Colección Théo Savary. 
Luego de esta introducción, ingresa en una narrativa etnográfica clásica que se refleja en la presentación y rol del cacique, armamentos, creencias, hábitos de caza, danzas, ornamentos, etc.

Es evidente que este texto fue realizado con posterioridad al viaje, y a continuación del mismo cierra afirmando la satisfacción de haber tenido la «... ocasión de ver y estudiar acerca de las costumbres, hábito y régimen de vida de tan curiosa tribu», Boccard introduce en el álbum un texto con una escritura rápida y con muchas tachaduras e incorporaciones, que parecería un borrador de un texto a revisar y que responde a los caracteres de un diario de viaje. Tanto en el anterior como en este texto, se ubica como un viajero exotista que buscaba tener contacto con esos «salvajes» de los que había oído hablar. Sin embargo, el texto ante citado tiene una estructura que revela un interés científico, mientras el segundo pone de manifiesto ciertos aspectos de la «vanguardia capitalista» a la que hace alusión Pratt: refiere a los obrajes - y los empresarios sin escrúpulos - a la posibilidad de construir prósperas colonias, citando el trabajo de un gobernador de Misiones. Tal como lo analizan Shohat y Stam atendiendo al discurso eurocéntrico contemporáneo, la mirada eurocéntrica de la historia es aquella que posiciona a Europa como el único motor del cambio y del progreso mundial ${ }^{55}$. Los empresarios que se citan en los epígrafes de las imágenes son en su mayoría europeos.

Este diario de viaje abunda en citas exotistas del paisaje, del descubrimiento de estas «tribus» que ni exploradores ni viajeros habían visto, de una naturaleza «misteriosa» y «lujuriante vegetación», y del reparo y prudencia ante los «guayaquíes», a quienes quiere «atraerlos y trabar amistad» ${ }^{56}$. Más de medio siglo después a los ejemplos que Pratt toma sobre las características de la «vanguardia capitalista», De Boccard se puede vincular a ésta, en espacios de reciente ocupación e interés. Al respecto, Pratt señala que «en los escritos de la vanguardia capitalista lo edénico y pastoril es reemplazado por una visión modernizante y codiciosa, muy bien ejemplificada por un tropo que podríamos llamar «ensoñación industrial» ${ }^{57}$.

Este concepto de «amistad» es el que vertebra las fotografías del álbum de esta expedición, y son las imágenes que eligirá para incorporarlas en otros álbumes, incluso el único impreso al que hicimos alusión. Además de las fotos de estancias y obrajes, establecimientos yerbateros, del trazado del tren «Decauville» para entrar en los obrajes, del rol de algunos extranjeros en

55 Shohat y Stam, 1994.

56 De Boccard, «Indios cainguas», Album Viajes \& Exploraciones a los Territorios del Alto Paraná, Paraguay, Misiones y Brazil 1898-1899, Colección Théo Savary.

57 Pratt, 1997: 264. 
estas actividades, fotos que justifican el interés extractivo y capitalista sobre las regiones, De Boccard (se) presenta con/a los indígenas en escenas de amistad, recurriendo a uno de los estereotipos de representación propios de la herencia colonial del indígena americano que responde al «indio manso».

IMAGEN 3. UNA PÁGINA DEL ÁLBUM VIAJES \& EXPLORACIONES A LOS Territorios del Alto Paraná, Paraguay, Misiones y Brazil, 1898-1899

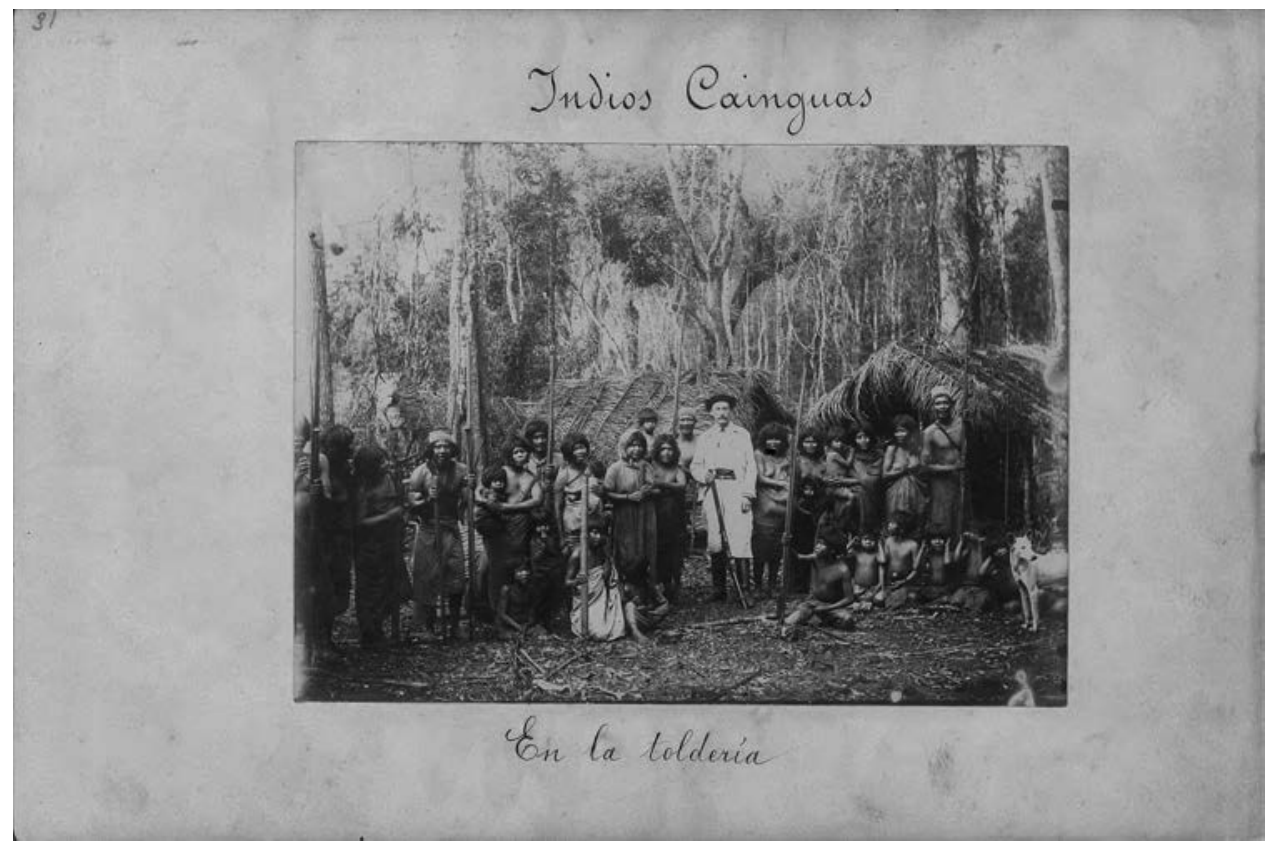

Colección Théo Savary.

Sin embargo, en este texto - que es re-escrito en tres oportunidades con enmiendas y tachaduras - Boccard presenta al guayaquí como «el hombre más primitivo que existe tal vez en toda la América del Sur; salvaje en todo sentido de la palabra que vive aún en el ambiente de la edad de piedra...»> Dos episodios en secuencia narrativa remiten a acciones de violencia explícita, de doble captura del indígena transformado en objeto: refiere a que un

58 De Boccard, Album Viajes \& Exploraciones a los Territorios del Alto Paraná, Paraguay, Misiones y Brazil 1898-1899, Colección Théo Savary. 
indio mestizo, al que llama Manoel y lo caracteriza como «famoso bandolero y terror de los pocos colonos», actuó de vaqueano en la expedición, y en un episodio confuso mata a una mujer guayaquí, hecho que es reprendido por De Boccard: «Lo reprendí enérgicamente por su acción que comparaba él como una sencilla hazaña de cazador y que yo clasifiqué como un nuevo crimen que había cometido... Previa fotografía de la India la ize enterar (sic) al pie de un árbol...» ${ }^{59}$ Doble captura del arma y de la imagen; recurso racional del autor de mostrar una región atrasada, y de posicionar su testimonio como una peripecia de la experiencia vital, donde el énfasis está puesto en sí mismo más que en el «otro» indígena. Naturalia y exotismo para el gabinete de curiosidades, aunque no hemos hallado la imagen a la que el texto hace referencia. El episodio de la muerte de la indígena continúa con un relato de profanación del cuerpo de la misma indígena por parte de Manoel, quien le cortó un seno para hacerle a De Boccard una tabaquera. La naturalidad del relato se completa con otras escenas de cacería de indígenas por parte de Manoel, que lindan entre la narrativa de viaje y la ficción literaria.

Estos episodios de violencia - si atenemos a la verdad del relato-, se encuentran invisibilizados por la fotografía. La narrativa visual, como señalamos, ubica a los expedicionarios en el contexto de un acercamiento amistoso con los grupos indígenas, donde éstos posan frente a la cámara con lanza y flechas, y por ello son identificados en los epígrafes como «guerreros», pero cuya pasividad referencial no es indicadora de peligrosidad. En el conjunto del álbum el texto de los epígrafes se emplea para conferir inmediatismo a los espacios y sujetos, sitúa espacialmente a la fotografía dando nombres a los personajes, lo que, en términos de Edwards ${ }^{60}$, supone un principio de autoridad que alude a la idea de «encuentro personal», y por eso varias de estas imágenes tuvieron una circulación más amplia en postales y en el álbum editado por De Boccard. Sin embargo, otro es el rol que asumen los textos que se incorporan al final del trayecto visual, los que asumen un carácter independiente de la imagen. Uno de ellos se inclina por una narrativa de interés etnográfico, mientras que el otro oscila entre el diario de viaje y la ficción literaria.

El segundo álbum de viaje que hemos hallado es el que tituló Viaje a los Territorios del Neuquén, Cordillera del Sur y Chile. Enero-mayo 190061, viaje

59 Idem.

${ }^{60}$ Edwards, 1992.

61 Colección Monges. La fecha de este viaje no coincide con el adelanto del mismo que realiza en una carta a sus padres de fines de 1900, donde dice que realizará ese viaje por encargo del gobierno argentino. Carta de Louis de Boccard a sus padres, Gualeguay, 5/12/1900, 
Imagen 4. Una PÁgina del Álbum VIAJE a lOS TERRITORIOS DEL NEUQuÉN, CoRDILLERA DEL SUR Y CHILE, ENERO-MAYO 1900

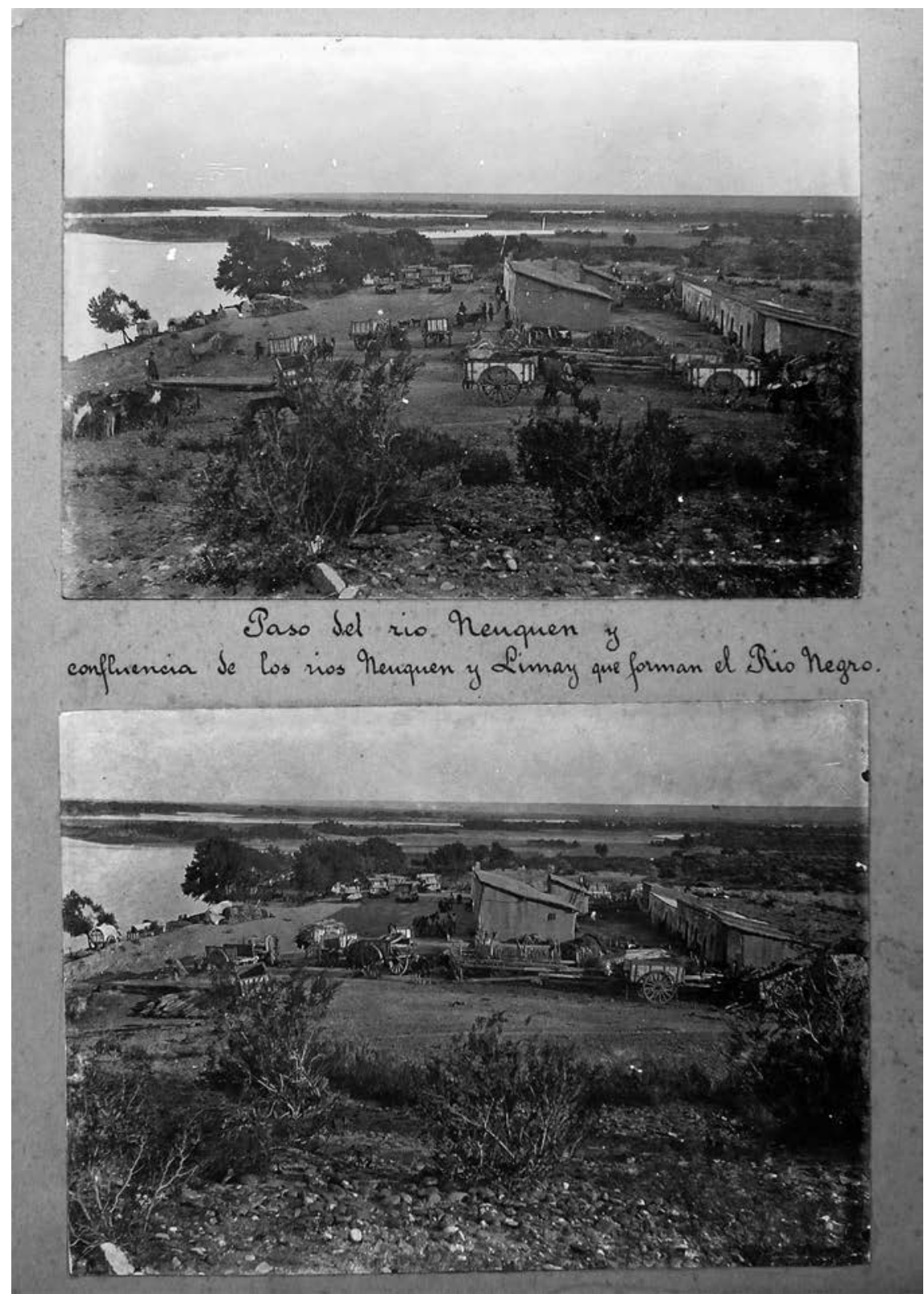

Colección Monges.

Revista de Indias, 2019, vol. LXXIX, n. ${ }^{\circ} 275,235-263$, ISSN: 0034-8341 https://doi.org/10.3989/revindias.2019.008 
del que, a diferencia del anterior, posee solamente fotografías, propias y de otros fotógrafos en formato postal. También contiene una narrativa semejante al anterior, donde las vistas de paisajes, de ciudades y las escenas étnicas guardan un rol significativo. Algunas de estas imágenes fueron comercializadas en formato postal, lo que pone en evidencia un aspecto diferencial en su uso, y también en la confección del álbum: ubica en una misma página el original y la postal de una estancia en Neuquén, esta última con sello postal, lo que evidencia su circulación. El interés naturalista se encuentra en el registro visual y descripción en los epígrafes de algunas especies vegetales, y serán éstas junto a fotografías de indígenas las que seleccionará para su circulación en formato postal. En ningún momento del álbum se advierte en forma explícita la problemática que según los comentarios de De Boccard originó el mismo como fue el de tratar, por encomienda del gobierno argentino, problemas limítrofes con Chile. Años después, en una semblanza de De Boccard, vuelve a insistir sobre este rol «diplomático» según una nota periodística publica Le Courrier Suisse referencia el Presidente Roca lo incorporó al Ministerio de Asuntos Exteriores argentino y le diera esta misión diplomática ${ }^{62}$.

Los últimos álbumes confeccionados sobre expediciones son dos versiones de una misma expedición, uno con fotografías, epígrafes y diario de viaje en francés, y otro en español, que sólo contiene fotografías con sus epígrafes. Se trata de la «Expedición Montt y Fialho al Alto Paraguay, Rio Apa y Matto Grosso dirigida por el explorador L. de Boccard (1924)» ${ }^{63}$. Los álbumes de la Expedición Montt y Fialho —encargados de negocios de Chile y Brasil-al Alto Paraguay, Rio Apa y Matto Grosso ${ }^{64}$ dirigida por el explorador L. de Boccard (1924), conjugan visualmente una mirada sobre el territorio, la vegetación, los animales salvajes que cazaban - la caza fue el objetivo explícito de la expedición - y la población indígena. Sin embargo el foco también

Colección Théo Savary. En diciembre de 1901 otra carta a sus padres anuncia un futuro viaje a Patagonia y Chile. Carta de Louis de Boccard a sus padres, Buenos Aires, 12/12/1901, Colección Théo Savary.

62 Le Courrier Suisse, Buenos Aires, 2 mayo 1942.

63 Sobre un análisis pormenorizado de estos dos álbumes véase Jarak y Giordano, 2014: 273-293.

${ }^{64}$ La versión en español integra la Colección Machuca. El álbum en francés se titula Expedition G. Montt \& O. Fialho Chargés d'Affairs du Chili et du Bresil au Haut Paraguay, Rio Apa et Matto Grosso. Dirigée par l'Explorateur Ls. de Boccard, Mars-Junio 1924. Si bien tiene las mismas imágenes que la versión en español, ésta — dedicada por Boccard a su madre - contiene la narrativa escrita al finalizar la parte de fotografías, que es titulada por Boccard como Histoire de l'Expedition (66 páginas manuscritas), e incorpora también artículos periodísticos de diarios de Asunción (2 páginas de recortes periodísticos). Este álbum se encuentra en la Colección Théo Savary. 


\section{Imagen 5. «Nuestro CaZador Manuel Frutos - SR. Montt} JUNTO CON LA BANDERA CHILENA》

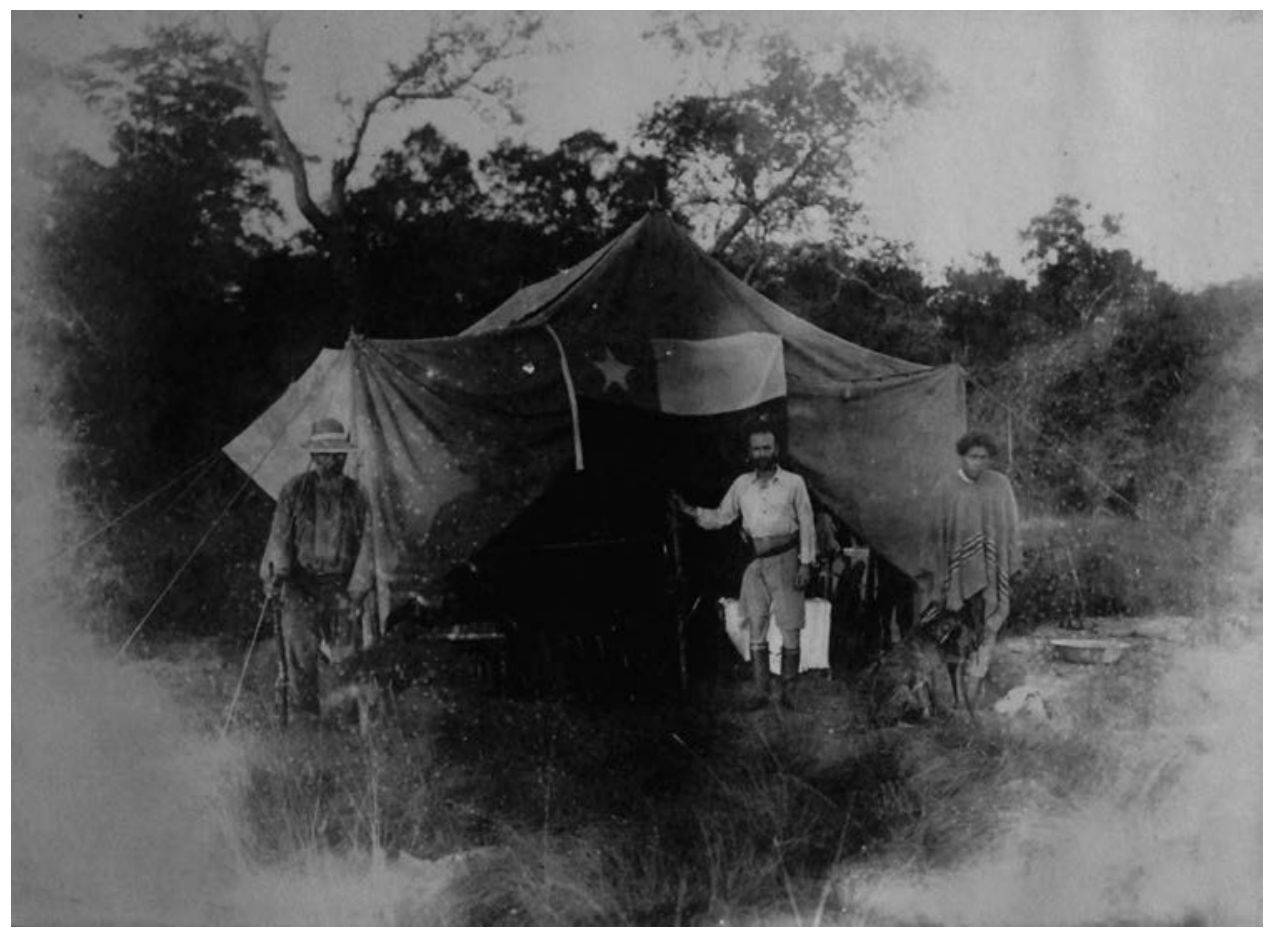

Album Expedition G. Montt \& O. Fialho Chargés d'Affairs du Chili et du Bresil au Haut Paraguay, Rio Apa et Matto Grosso. Dirigée par l'Explorateur Ls. de Boccard, marzo-junio 1924, Colección Machuca.

está puesto en los medios de comunicación terrestres y fluviales, en las diversas actividades extractivas en las estancias que se recorren donde las plantaciones de caña de azúcar que están especialmente documentadas, y en las escasas actividades industriales como los saladeros de carne, construyendo imágenes que adquieren particular interés por adherirse al paradigma extractivo y maximizador del capitalismo al que ya hicimos referencia. En el diario de viaje Boccard hace referencia en repetidas oportunidades a los propietarios o gerentes de las estancias que recorrían, a quienes consideraba sus amigos, todos ellos de origen europeo.

La presencia de Montt y Fialho, a quienes Boccard guía en esta expedición, es central en el rol de cultural broker de este personaje. Ambos participaban de actividades diplomáticas en el Paraguay en representación de Chile y Bra- 
sil, y Boccard se refiere a ellos como «mis dos amigos diplomáticos» ${ }^{65}$. Es importante atender también al carácter geopolítico del itinerario de esta expedición, en territorios que pocos años después serán zona de litigio en la Guerra del Chaco entre Bolivia y Paraguay, donde el mismo Gonzalo Montt participará como oficial chileno voluntario en la contienda.

Así, la fotografía ocupó un lugar central en todas sus expediciones: en los casos en que relata las experiencias expedicionarias, dedica largos párrafos para referirse a las tomas y a los fotógrafos, en ocasión en que lo acompañaba un fotógrafo profesional. En la expedición a la Patagonia realizada con Anchorena en 1901 — de la que no poseemos álbum-, menciona que aprovechó dos o tres días de descanso para sacar varias fotos del viaje que enviará a su familia. Pero aclara que la expedición tendrá un magnífico álbum, ya que se sacaron más de 400 fotografías con cinco aparatos diferentes ${ }^{66}$. Si bien no conocemos la existencia de un álbum de esta expedición realizado por De Boccard - que pudo haberse perdido, dado que su correspondencia plantea la intención de realizarlo-, publicó algunas de esas fotos en el pequeño álbum antes mencionado, el único impreso. Anchorena, por su parte, hizo público una gran cantidad de imágenes que corresponderían a las referidas por De Boccard.

Asimismo, en la expedición Montt y Fialho, De Boccard hace referencia a que llevaban tres cámaras de fotos, y que uno de los dos suizos contratados para acompañarlos en la expedición tenía algunos conocimientos de fotografía.

A la vez, el álbum - los álbumes - en tanto artefactos, construyen una mise en scène que desde lo artefactual condensa lo personal, lo científico, lo documental, lo estético y lo objetual, y resulta ser un rompecabezas de múltiples dimensiones de sentido biográfico - y autobiográfico desde su autor-, del cual este texto es, sólo una de las posibles entradas.

\section{A MODO DE CIERRE}

La colección de Louis de Boccard, en su conjunto, nos presenta espacios, sujetos y rostros singulares. Son presencias, pero también la fotografía supone la ausencia, o el recorte, lo que «falta». Narrativa visual y textual remiten a cuestiones de colonialidad, de identidad, de memoria, de discriminación y

65 De Boccard, «Histoire de 1'Expedition», en Expedition G. Montt \& O. Fialho Chargés d'Affairs du Chili et du Bresil au Haut Paraguay, Rio Apa et Matto Grosso. Dirigée par l'Explorateur Ls. de Boccard, marzo-junio 1924, Colección Machuca.

66 Carta de Louis de Boccard a sus padres, Lago Nahuel Huapi, 20 de marzo de 1902, Colección Théo Savary. 
racismo, de conocimiento, con una densidad significante que nos imposibilita hablar de verdad, sino de verosimilitud, con un personaje central como productor de estas narrativas, que se posiciona en y a través de diversas estrategias como un mediador cultural a través de los mismos objetos que produce y colecciona. Pero que a la vez se pone en diálogo con otros tantos sujetos-objetos de sus representaciones.

Lo curioso, lo anormal, lo «salvaje», junto a lo cotidiano, lo doméstico y lo habitual constituyen este universo artefactual de coleccionismo, de intercambio, de itinerarios geográficos y visuales, de los cuales este texto es sólo una aproximación, que conlleva una subjetividad espectatorial-autoral que se asume hasta las últimas líneas.

En su itinerancia, Louis de Boccard va construyendo visualmente un mundo social que se nutre de intereses científicos —en particular naturalistas de imaginarios previos sobre el mundo americano y de un universo objetual que reúne. Esa movilidad que conserva la capacidad de observación del flâneur citadino convertido en explorador, es un sustrato de conocimiento. Los vínculos académicos, políticos y sociales que establece están mediatizados en gran parte por la agencia de los objetos, y de él mismo como agente primario. Es De Boccard quien ha permitido que los objetos extiendan su itinerancia y subjetividad, pero también las sucesivas reapropiaciones de aquellos por nuevos coleccionistas y por nosotros, que incluyéndome en el genérico de «investigadores», hemos re(construido) esa biografía cultural de los objetos, como «fragmentos eleáticamente recortados», en las palabras de Cortázar que reproducíamos al inicio de este texto.

\section{BIBLIOGRAFÍA}

Anchorena, Aarón, Excursión a la Patagonia y a los Andes, Buenos Aires, Compañía Sud-Americana de Billetes de Banco, 1902.

Appadurai, Arjun (ed.), La vida social de las cosas. Perspectiva cultural de las mercancías, México, Grijalbo, 1991.

Ares Queija, Berta y Gruzinski, Serge, «Presentación», Berta Ares Queija y Serge Gruzinski (coords.), Entre dos mundos. Fronteras culturales y agentes mediadores, Sevilla, Escuela de Estudios Hispano-Americanos, 1997: 9-11.

Arfuch, Leonor, Memoria y autobiografia. Exploraciones en los límites, Buenos Aires, Fondo de Cultura Económica, 2013.

Baudelaire, Charles, «Le peintre de la vie moderne», Curiosités esthétiques. Euvres complètes, París, Gallimard, 1954. 
Baudrillard, Jean, «The system of collecting», John Elsner y Roger Cardinal (eds.), The cultures of collecting, Londres, Reaktion Books, 1994: 7-24.

Bauman, Zygmunt, Flâneure, Spieler und Touristen, Essays zu postmodernen, Hamburg, Lebensformen, 1997: 136-159.

Bleichmar, Daniela y Mancall, Peter (eds.), Collecting across cultures: material exchanges in the early Modern Atlantic World, Filadelfia, University of Pennsylvania Press, 2013.

Boëtsch, Gilles, «From Cabinets of Curiosities to the passion for the "Sauvage"», Pascal Blanchard, Gilles Boëtsch y Nanette Jacomijn Snoep (eds.), Human Zoos. The Invention of the Sauvage, Paris, Musée du Quai Branly, 2012: 78-97.

Cortázar, Julio, Rayuela, Alfaguara, Buenos Aires, 2013.

De Boccard, Louis, Unas Vistas de las Expediciones y Viajes del explorador de Boccard en la América del Sud, Genéve, Societé de Arts Grafique, s/f.

De Courten, Regis, «Don Luis de Boccard explotador en Argentine et au Paraguay», Les Fribourgeois sue la planette/Die Freiburger in aller welt, Fribourg, Bibliothèque Cantonale et Universitaire, 1987: 141-153.

Dickie, George, El círculo del arte. Una teoría del arte, Buenos Aires, Paidos, 2005.

Edwards, Elizabet, Anthropology \& Photography. 1860-1920, London, Yale University Press, 1992.

Farro, Máximo, La formación del Museo de La Plata. Coleccionistas, comerciantes, estudiosos y naturalistas viajeros a fines del siglo XIX, Rosario, Prohistoria, 2009.

García, Germán, «Cuerpo, mirada y muerte», Paula Croci y A. Vitale (comps.), Los cuerpos dóciles. Hacia un tratado sobre la moda, Buenos Aires, La Marca, 2000: 159-162.

Gell, Alfred, Art and Agency: an antropological theory, Oxford, Claredon Press, 1998.

Halbwachs, Maurice, On collective memory, Chicago, University of Chicago Press, 1992.

Jarak, Diego y Giordano, Mariana, «Visualiser les territoires de l'attente. Le cas Louis de Boccard», Laurent Vidal y Alain Musset (coords.), Les territoires de l'attente. Migrations et mobilités dans les Ameriques (XIXE $-X X I^{E}$ Siècle), Rennes, Presses Universitaires de Rennes/Institute des Ameriques, 2014: 273-293.

Kopytoff, Igor, «La biografía cultural de las cosas: La mercantilización como proceso», Arjun Appadurai (ed.), La vida social de las cosas. Perspectiva cultural de las mercancías, México, Grijalbo, 1991: 89-122.

Lizarazo, Diego, Iconos, figuraciones, sueños. Hermenéutica de las imágenes, México DF., Siglo XXI, 2004. 
Martin, Meredith y Bleichmar, Daniela, «Objects in Motion in the Early Modern World», Art History, 38/4 (United Kingdom, 2015): 604-609, doi: 10.1111/14678365.12170 .

Masotta, Carlos, «Telón de fondo. Paisajes del desierto y alteridad en la fotografía de la Patagonia (1880-1900)», Aisthesis, 46 (Santiago de Chile, 2009): 111-127.

Mills, Kennet, «"In between”: reflexiones sobre el mestizaje cultural y la movilidad en los Andes Coloniales», Ponencia presentada el taller El mestizaje como problema de investigación, Bernal, Universidad Nacional de Quilmes, 2004.

Podgorny, Irina, "A charlatan's album: cartes-de-visite from Bolivia, Argentina and Paraguay (1860-1880)», Maja Kominko (ed.), From Dust to Digital. Ten years of the Endangered Archives Programme, Cambridge, Open Book Publishers, 2015: 417-443. http://dx.doi.org/10.11647/OBP.0052

Pratt, Mary Louise, Ojos imperiales. Literatura de viajes y transculturación, Buenos Aires, Universidad Nacional de Quilmes, 1997.

Shohat, Ella y Stam, Robert, Unthinking Eurocentrism: Multiculturalism and the Media, New York, Routledge, 1994.

Wolf, Rudolf, «Aspects of group relations in a complex society: Mexico», American Anthropologist, New Series, 58/6 (Washington, 1956): 1065-1078.

Fecha de recepción: 23 de junio de 2016.

Fecha de envío de las modificaciones: 17 de septiembre de 2016.

Fecha de aceptación: 21 de septiembre de 2016.

\section{Expeditions, photography and collecting between two centuries. Visual itineraries of a "cultural broker" in Argentina and Paraguay}

This paper analyses the network of visuality, artifactuality and collecting in the life of Louis de Boccard, a "cultural broker" who lived in and toured Argentina and Paraguay between the late nineteenth century and the twentieth century. His collection is constructed from a visual and textual narrative that refers to topics of colonialism, identity, memory, knowledge, with a significant density where photography and the album play relevant roles. Albums are analysed through an interaction between the visible and expressible dimensions.

Key WORDS: Argentina-Paraguay; photography; collecting; Louis de Boccard. 